\title{
Genetic characterization of selected Nile tilapia in Santa Catarina
}

\section{Caracterização genética de tilápia-do-nilo selecionadas em Santa Catarina}

\author{
Bruno Corrêa da Silva ${ }^{*}$; Adriana Pereira ${ }^{2}$; Haluko Massago ${ }^{1}$; \\ Keny Henrique Mariguele ${ }^{3}$
}

Highlights:

The study allowed the genotypic characterization of the tilapia stock used in Santa Catarina.

There is high heterozygosity within the tilapia brook stock.

There is moderate genetic differentiation between tilapia brook stocks.

All markers evaluated were polymorphic for this stock and will be used for future evaluations.

\begin{abstract}
Different Nile tilapia stocks belonging to the fish breeding program of the Epagri (Empresa de Pesquisa Agropecuária e Extensão Rural de Santa Catarina) were characterized by microsatellite markers. A total of nine stocks (S1 to S9) were evaluated, and for each stock the caudal fin of 30 individuals were sampled. A total of 75 alleles were found at the 11 microsatellite loci used (UNH104, UNH108, UNH160, UNH208, UNH222, UNH848, UNH879, UNH898, UNH952, UNH998). Among the loci used, only UHN160 showed significance for null alleles in stocks S1, S2, S3 and S5. The average number of alleles per loci was 6.8, while the average number of alleles per tilapia stock was 4.4. Five unique alleles were identified between the stock S1 and S5. The observed heterozygosity values (Ho) exceeded the expected heterozygosity $(\mathrm{He})$, resulting in a negative inbreeding coefficient $\left(\mathrm{F}_{\mathrm{IS}}=-0.092\right)$. $\mathrm{F}_{\mathrm{ST}}$ for the total population was 0.109 , demonstrating moderate genetic differentiation between the stocks. According to the Euclidean distance, three groups were formed as follows: I - S6, S7 and S9; II - S2, S3 and S4; and III - S1, S5 and S8. However, the existence of two groups can be observed from the PCoA representation: I - S6, S7, S8 and S9; and II - S1, S2, S3, S4 and S5. The formation of these two genetic groups is consistent with the genealogy of stocks. The formation of group III (S1, S5 and S8) in the dendrogram can be explained by the higher average observed heterozygosity values of these stocks. Bayesian analysis revealed the formation of 16 groups with an $\mathrm{F}_{\mathrm{ST}}$ value of 0.2107 . This result reinforces the existence of variability existing in the Epagri breeding program, from which it is possible to form heterotic groups to enable the direction of potential crosses to obtain genetic gain. The study enabled genotypic characterization of the tilapia brood stock used in the Epagri breeding program, determining the genetic distance between the stocks, which will enable more accurate selection of individuals for mating for the next generation. It was possible to verify that there is high heterozygosity within the stocks, and moderate genetic differentiation between the stocks. Furthermore, all evaluated markers were polymorphic for this brood stock and will be used to characterize the next generations.
\end{abstract}

Key words: Oreochromis niloticus. Genetic variability. Microsatellite markers.

\footnotetext{
1 Pesquisadores, Drs., Empresa de Pesquisa Agropecuária e Extensão Rural de Santa Catarina, Epagri, Centro de Desenvolvimento em Aquicultura e Pesca, Cedap, Itajaí, SC, Brasil. E-mail: brunosilva@epagri.sc.gov.br, halukomassago@epagri.sc.gov.br

2 Pesquisadora, M.e, Epagri, Estação Experimental de Itajaí, EEI, Itajaí, SC, Brasil. E-mail: adriana@epagri.sc.gov.br

3 Pesquisador, Dr., Epagri, Estação Experimental de Itajaí, EEI, Itajaí, SC, Brasil. E-mail: kenymariguele@epagri.sc.gov.br

* Author for correspondence
}

Received: June 01, 2019 - Approved: Jan. 07, 2020 


\section{Resumo}

Diferentes plantéis de tilápia-do-nilo pertencentes ao programa de melhoramento genético de peixes da Epagri (Empresa de Pesquisa Agropecuária e Extensão Rural de Santa Catarina) foram caracterizados por meio de marcadores microssatélites. Ao total foram avaliados nove plantéis (S1 a S9), e para cada foram amostrados nadadeira caudal de 30 indivíduos. O total de 75 alelos foram encontrados nos 11 loci microssatélites utilizados (UNH104, UNH108, UNH160, UNH208, UNH222, UNH848, UNH868, UNH879, UNH898, UNH952, UNH998). Entre os loci utilizados, apenas o UHN160 apresentou significância para alelos nulos nos estoques S1, S2, S3 e S5.A média do número de alelos por loci foi 6,8 , enquanto a média do número de alelos por plantel de reprodutores foi 4,4. Foram encontrados cinco alelos exclusivos entre os plantéis S1 e S5. Os valores de heterozigosidade observada (Ho) foi maior do que a esperada $(\mathrm{He})$, resultando em um coeficiente de endogamia $\left(\mathrm{F}_{\mathrm{IS}}\right)$ médio negativo $(-0,092)$. O $\mathrm{F}_{\mathrm{ST}}$ encontrado para a população total foi de 0,109 , evidenciando moderada diferenciação genética entre os plantéis. De acordo com a distância euclidiana, três grupos foram formados da seguinte forma: I - S6, S7 e S9; II - S2, S3 e S4; e III - S1, S5 e S8. Porém, a partir da representação do PCoA, observa-se a existência de dois grupos: I - S6, S7, S8 e S9; e II - S1, S2, S3, S4 e S5. A formação desses dois grupos genéticos é consistente com a genealogia dos plantéis de reprodutores. A formação do grupo III (S1, S5 e S8) no dendrograma pode ser explicada pelos maiores valores médios de heterozigosidade observados desses plantéis. A análise bayesiana mostrou a formação de 16 grupos com um valor de Fst de 0,2107. Esse resultado reforça a existência de variabilidade existente no programa de melhoramento Epagri, a partir do qual é possível formar grupos heteróticos para permitir cruzamentos potenciais para obter ganho genético. O estudo permitiu a caracterização genotípica dos plantéis de reprodutores de tilápia utilizado no programa de melhoramento Epagri, determinando a distância genética entre eles, o que permitirá a seleção mais precisa dos indivíduos para os acasalamentos da próxima geração. Foi possível verificar que há alta heterozigosidade entre os plantéis de reprodutores e moderada diferenciação genética entre eles. Além disso, todos os marcadores avaliados foram polimórficos para este estoque de matrizes e serão utilizados para caracterizar as próximas gerações.

Palavras-chave: Oreochromis niloticus. Variabilidade genética. Marcadores microssatélites.

\section{Introduction}

Nile tilapia, Oreochromis niloticus Linnaeus 1758 (Osteichthyes: Cichlidae), stands out as the species with the greatest potential for continental aquaculture, given its fast growth, easy adaptation to farm conditions and meat quality (Webster \& Lim, 2006). In recent years, its cultivation in Brazil has increased by $14.2 \%$ per year, with higher protein production than other animals such as cattle $(5.1 \%)$, pigs (2.9\%) and broilers (4.1\%) (Kubitza, 2015). In 2017, Brazilian production of farmed fish was around 692 thousand tons, and tilapia represented $51.7 \%$ of this weight (Associação Brasileira da Piscicultura [PeixeBR], 2018).

In Santa Catarina, the production of freshwater fish was 44,500 tons in 2017, and tilapia accounted for $74 \%$ of this weight (PeixeBR, 2018). The tilapia strain most produced in this state is GIFT, short for Genetically Improved Farmed Tilapia (Barroso et al., 2016). This was a strain selected for growth, reproduction, weight gain and fillet yield. However, its breeding was carried out in countries with a tropical climate, selecting animals more adapted to that condition (Bentsen et al., 2017).

In 2005, the Nile tilapia GIFT strain was introduced in Brazil by the Maringá State University (UEM) with the help of the Special Secretariat of Aquaculture and Fisheries, and later it was introduced by Epagri (Empresa de Pesquisa Agropecuária e Extensão Rural de Santa Catarina) in Santa Catarina. Aiming at the selection of tilapia with higher weight gain, more adapted to the climatic conditions of Santa Catarina and the distribution of this genetic material to the producers of fingerlings 
in the state, who are mostly family farmers, Epagri started an individual selection program for tilapia (GIFT strain) in 2011 (Halfen, Nicoletti, Appel, \& Tcacenco, 2012).

Individual selection can lead to a rapid decrease of genetic variability through generations. Low genetic variability may reduce selection response in the breeding program, in addition to declining zootechnical performance (Rodriguez-Rodriguez et al., 2013). Therefore, knowledge of the genetic characteristics of the breeding stock is fundamental, making it important to evaluate polymorphism among the stock that will be used for mating in the breeding program (Gjedrem, 2010; Moraes, Saldanha, Rezende, \& Sousa, 2017).

Studies of genetic variability of tilapia have been carried out mainly through microsatellite markers (Romana-Eguia, Ikeda, Basiao, \& Taniguchi, 2004; Hassanien \& Gilbey, 2005; Moreira, Hilsdorf, Silva, \& Souza, 2007; Briñez, Caraballo, \& Salazar, 2011; Petersen et al., 2012; Rodriguez-Rodriguez et al., 2013). This is a popular and versatile technique with many applications in population genetics, being a powerful tool that is capable of detecting genetic variation between individuals, species or populations (Joshi, Ram, \& Lohani, 2017).

Petersen et al. (2012) evaluated the genetic variability of three tilapia varieties produced in Santa Catarina and reported a lower rate of inbreeding in GIFT tilapia. According to the authors, these results reflect the history of controlled mating in this strain, since the other strains had already been in the state for longer without this control. The results of the study by Petersen et al. (2012) reinforce the importance of periodic evaluation of the genetic variability of the brood stock for directing mating in the breeding program.

Therefore, this study aimed to carry out genotypic characterization and to determine the genetic diversity within and between the different brood stock in the breeding program of Nile tilapia conducted by Epagri.

\section{Materials and Methods}

GIFT tilapia from Epagri's breeding program of UMGEP (Unidade de Melhoramento genético de peixes da Epagri) were used in the study. All procedures were conducted in accordance with the Animal Maintenance Ethics Committee standards and procedures and approved by CEUA - No. 224/2017.

In December 2015, a total of 270 males and 450 females were selected from nine different stocks of tilapia from the second generation of the GIFTEpagri program. From each stock of 1500 cultivated tilapia, 30 males and 50 females with the highest final weight were selected.

For each of the nine stocks (S1 to S9), 30 individuals were sampled and tagged with a passive integrated transponder (PIT). A caudal fin sample of approximately $2.0 \mathrm{~cm}^{2}$ was collected from each animal; these were preserved in $70 \%$ ethanol at $-20^{\circ} \mathrm{C}$ for DNA extraction.

DNA extraction was performed using the modified protocol of Aljanabi and Martinez (1997) which uses high concentrations of $\mathrm{NaCl}$. Modifications included a one hour incubation in lysis buffer and the precipitation of DNA with isopropanol. DNA quality and quantity were measured in a biophotometer (Eppendorf, Germany). After quantification, the samples were standardized to 20 ng DNA per $\mu \mathrm{L}$.

The 11 SSR loci were amplified using specific primers (Table 1). These markers were synthesized by adding the 5'- M13 tail at the forward primer of each marker to enable the use of fluorescently labeled universal primers according to Schuelke (2000). Four different fluorophores were used for the primer labeling (6-FAM, VIC, NED and PET). The reaction mixture contained $40 \mathrm{ng}$ of DNA, $1 \times$ PCR buffer, $1.5 \mathrm{mM}$ of $\mathrm{MgCl}_{2}, 0.2 \mathrm{mM}$ of each dNTP, $0.2 \mu \mathrm{M}$ of reverse primer, $0.4 \mu \mathrm{M}$ of forward primer with M13 tail, $0.4 \mu \mathrm{M}$ of the fluorescently labeled universal M13 primer and 1.0 U of Taq DNA polymerase (Invitrogen, Carlsbad CA, USA), in a final volume of $25 \mu \mathrm{L}$. 
The reactions were carried out in a Veriti corresponding to the locus-specific primer, and 1 thermocycler (Applied Biosystems, Carlsbad CA, min at $72^{\circ} \mathrm{C}$, (iii) 8 cycles of $45 \mathrm{~s}$ at $95^{\circ} \mathrm{C}, 45 \mathrm{~s}$ at USA) with the following program: (i) an initial $53^{\circ} \mathrm{C}$, and $1 \mathrm{~min}$ at $72^{\circ} \mathrm{C}$ and (iv) a final extension denaturation step for $5 \mathrm{~min}$ at $95^{\circ} \mathrm{C}$, (ii) 30 cycles step for $30 \mathrm{~min}$ at $72^{\circ} \mathrm{C}$.

of $45 \mathrm{~s}$ at $95^{\circ} \mathrm{C}, 45 \mathrm{~s}$ of annealing at the temperature

Table 1

SSR markers, and their respective primer sequences and annealing temperature, used in the genetic characterization of selected Nile tilapia in Santa Catarina

\begin{tabular}{|c|c|c|c|}
\hline Loci & $\begin{array}{c}\text { Annealing } \\
\text { temperature }\left({ }^{\circ} \mathrm{C}\right)\end{array}$ & Primer sequence $\left(5^{\prime}-3^{\prime}\right)$ & Genbank \\
\hline UNH 104 & 56 & $\begin{array}{l}\text { F- GCAGTTATTTGTGGTCACTA } \\
\text { R- GGTATATGTCTAACTGAAATCC }\end{array}$ & G12257 \\
\hline UNH 108 & 56 & $\begin{array}{c}\text { F- GGGATCAGCTGTTAAGTTT } \\
\text { R- TGAGTTGATTATTAATTTCTGA }\end{array}$ & G12261 \\
\hline UNH 160 & 56 & $\begin{array}{c}\text { F - CCATTGGCTCTTACATC } \\
\text { R- GATAGCATTTCTGTAGTTATGG }\end{array}$ & G12312 \\
\hline UNH 208 & 56 & $\begin{array}{l}\text { F - CTTCTTGGCCTACAATTT } \\
\text { R - CAGATGGGTGATAGCAA }\end{array}$ & G12359 \\
\hline UNH 222 & 56 & $\begin{array}{l}\text { F-CTCTAGCACACGTGCAT } \\
\text { R-TAACAGGTGGGAACTCA }\end{array}$ & G12373 \\
\hline UNH 848 & 54 & $\begin{array}{c}\text { F - TCCCCCGTAATAAATTAAACCA } \\
\text { R - GCCTGTGAATAACAATGTATTTCCT }\end{array}$ & G68186 \\
\hline UNH 868 & 56 & $\begin{array}{l}\text { F - TCCTTGTTCAGACCTTGTGG } \\
\text { R - AGCCAGGCTGAAAGGAAATA }\end{array}$ & G68199 \\
\hline UNH 879 & 56 & $\begin{array}{l}\text { F - GCATAAGGTGACTGGCTGGT } \\
\text { R - ACAAAGGGGTCCTGCAATTT }\end{array}$ & G68206 \\
\hline UNH898 & 56 & $\begin{array}{c}\text { F - GATGTCCCCACAAGGTATGAA } \\
\text { G - TAATCCACTCACCCCGTTTC }\end{array}$ & G68215 \\
\hline UNH 952 & 56 & $\begin{array}{c}\text { F - CAGACTGATGGCACAGAGGA } \\
\text { R - TCTGCAATAGTGGCCATGAA }\end{array}$ & G68249 \\
\hline UNH 998 & 58 & $\begin{array}{l}\text { F - TCAATTGGTTTTACAGGAACACA } \\
\text { R - GCTGAGGTCAGCTTACATGTCT }\end{array}$ & G68277 \\
\hline
\end{tabular}


Amplified fragment pattern analysis was performed in an $\mathrm{AB} 3130$ automatic gene analyzer (Applied Biosystems, Carlsbad CA, USA) with $36 \mathrm{~cm}$ capillary and POP7 polymer. The band amplification data were annotated in number of base pairs (bp), according to the genotyping provided by the GeneMapper 4.0 program (Applied Biosystems, Carlsbad CA, USA).

The presence of null alleles was verified using the software Micro-Checker 2.2.3 (Van Oosterhout, Hutchinson, Wills, \& Shipley, 2004). The frequency of null alleles at each locus was estimated as in Brookfield (1996), using estimator number 1:

$$
\hat{r}=(H e-H o) /(1+H e)
$$

The software GeneAlEx 6.5 (Peakall \& Smouse, 2006) was used for statistical analysis of genotypic characterization, allele frequency and number of alleles per loci, observed heterozygosity (Ho) and expected heterozygosity (He), Hardy-Weinberg equilibrium (HWE), inbreeding coefficient $\left(\mathrm{F}_{\text {IS }}\right)$ and fixation index $\left(\mathrm{F}_{\mathrm{ST}}\right)$. Effective number of alleles (Ae) was calculated using the following formula: $\mathrm{Ae}=1 / \Sigma \mathrm{xi}^{2}$, where $x i$ is the frequency of each allele per loci. Analysis of Molecular Variance (AMOVA), with 9,999 random permutations, and Principle Coordinate Analysis (PCoA), based on Nei's genetic distances, were also performed using software GenAlEx 6.5. A dendrogram derived from Ward's method using Euclidean distance was constructed using software Past 3.15 (Hammer, Harper, \& Ryan, 2001).
A Bayesian model implemented by the software Structure 2.3.4 (Pritchard, Stephens, \& Donnelly, 2000; Falush, Stephens, \& Pritchard, 2003) was applied to infer the number of population groups. The population inference produced was performed without incorporating predefined population information for the mixed model and with correlated frequency. Population number analysis $(\mathrm{K})$ was performed for values ranging from 1 to 30 with ten independent chains, each chain having a length of 50,000 iterations, followed by 100,000 repetitions of the Markov chain Monet Carlo (MCMC) method.

\section{Results and Discussion}

Among the loci used, only UHN160 showed significance for null alleles in stocks S1, S2, S3 and S5 (Table 2). The presence of null alleles in the loci induces genotyping error, which can result in observed heterozygous deficit, causing HardyWeinberg equilibrium deviation. Table 3 shows the data generated from the genotyping microsatellite marker of the nine brood stock studied. Eleven loci analyzed showed polymorphism, with 75 alleles in total. The UNH898 and UNH952 loci were the microsatellite markers that showed the highest alleles numbers with ten alleles each. On the order hand the UNH108, UNH160, UNH222 and UNH868 markers showed only five alleles each. Considering all brood stock, the average of the total number of alleles per loci was 6.8 , while the average number of alleles per brood stock was 4.4 , with high similarity among the brood stock (3.7 to 5.4$)$. 
Table 2

Null allele frequency at 11 SSR loci for nine breed stock of Nile tilapia from the Epagri breeding program

\begin{tabular}{cccccccccc}
\hline Loci & S1 & S2 & S3 & S4 & S5 & S6 & S7 & S8 & S9 \\
\hline UNH104 & 0.029 & -0.154 & -0.182 & -0.091 & -0.114 & -0.042 & -0.008 & -0.053 & -0.035 \\
UNH108 & 0.039 & 0.050 & 0.006 & -0.096 & -0.078 & -0.012 & -0.086 & -0.193 & -0.102 \\
UNH160 & $0.248^{*}$ & $0.274^{*}$ & $0.149^{*}$ & -0.159 & $0.118^{*}$ & 0.007 & 0.016 & -0.178 & -0.097 \\
UNH208 & -0.119 & $-0,014$ & -0.075 & 0.086 & -0.003 & -0.055 & -0.019 & 0.000 & -0.038 \\
UNH222 & 0.050 & 0.001 & -0.047 & -0.082 & -0.023 & -0.002 & -0.061 & 0.023 & -0.012 \\
UNH879 & -0.063 & $-0,088$ & -0.129 & -0.063 & -0.041 & -0.121 & 0.060 & -0.130 & -0.111 \\
UNH898 & -0.202 & 0.066 & 0.067 & -0.037 & -0.009 & -0.060 & 0.056 & -0.072 & 0.071 \\
UNH998 & -0.127 & 0.172 & -0.016 & -0.066 & 0.063 & -0.027 & -0.124 & -0.061 & -0.031 \\
UNH952 & -0.036 & 0.011 & -0.066 & -0.091 & 0.054 & 0.019 & -0.106 & -0.137 & -0.085 \\
UNH868 & -0.154 & $-0,084$ & -0.055 & -0.023 & -0.096 & -0.018 & -0.020 & 0.002 & -0.037 \\
UNH848 & -0.021 & $-0,141$ & -0.205 & -0.051 & -0.122 & -0.010 & -0.140 & -0.091 & -0.085 \\
\hline
\end{tabular}

Estimator Brookfield 1 (1996); *P $<0.05$.

Petersen et al. (2012) evaluated the genetic variability of different tilapia strains cultivated in Santa Catarina (GIFT, Panama and red tilapia) and reported a total of 83 alleles with four microsatellite markers. With the GIFT strain, the authors observed a total of 12 alleles for the UNH104, UNH108 and UNH160 markers, a number higher than that found in this study for these same markers (6 to 7 alleles) (Table 3). The selection process applied in the Epagri brood stock over the last five years may explain this lower number of alleles. However, other studies with GIFT tilapia in Brazil, using a smaller number of animals and markers, showed a mean number of alleles per loci between 4.2 and 6.1 (Rodriguez-Rodriguez et al., 2013; Baggio, OrélisRibeiro, \& Boeger, 2016; Dias, Freitas, Arranz, Villanova, \& Hilsdorf, 2016), which is lower than that found in this study. 


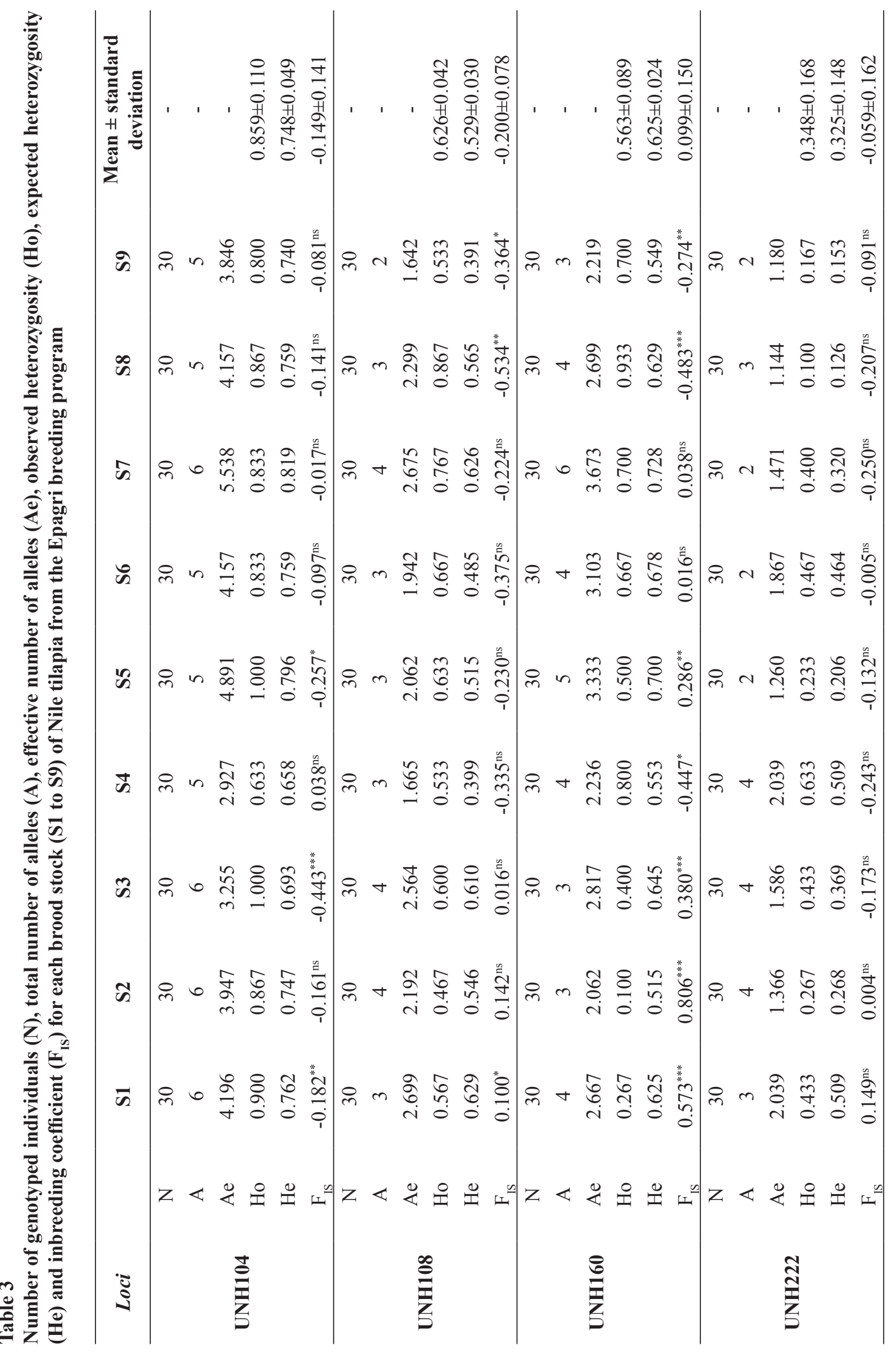

Semina: Ciências Agrárias, Londrina, v. 41, n. 5, p. 1739-1754, set./out. 2020 


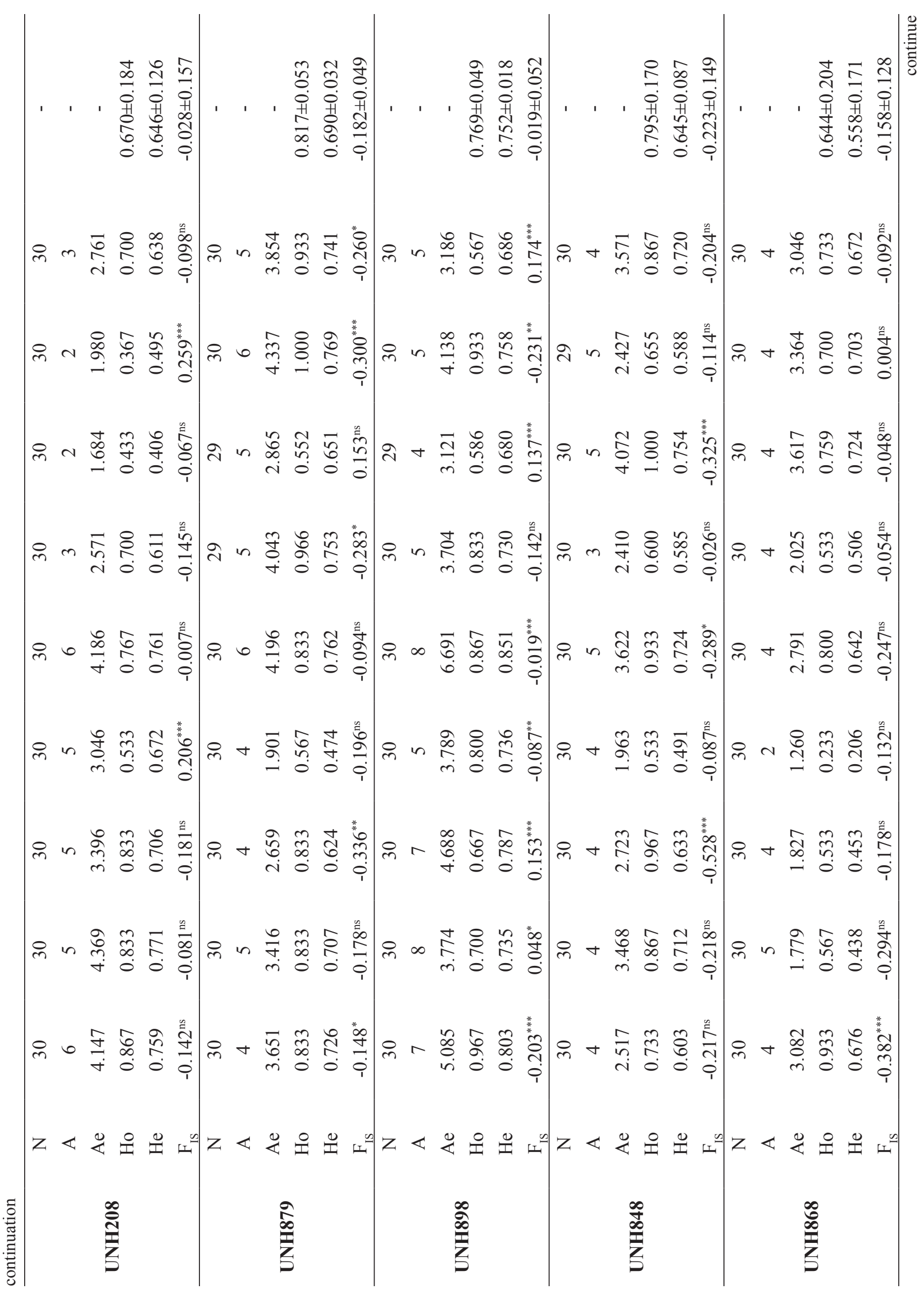




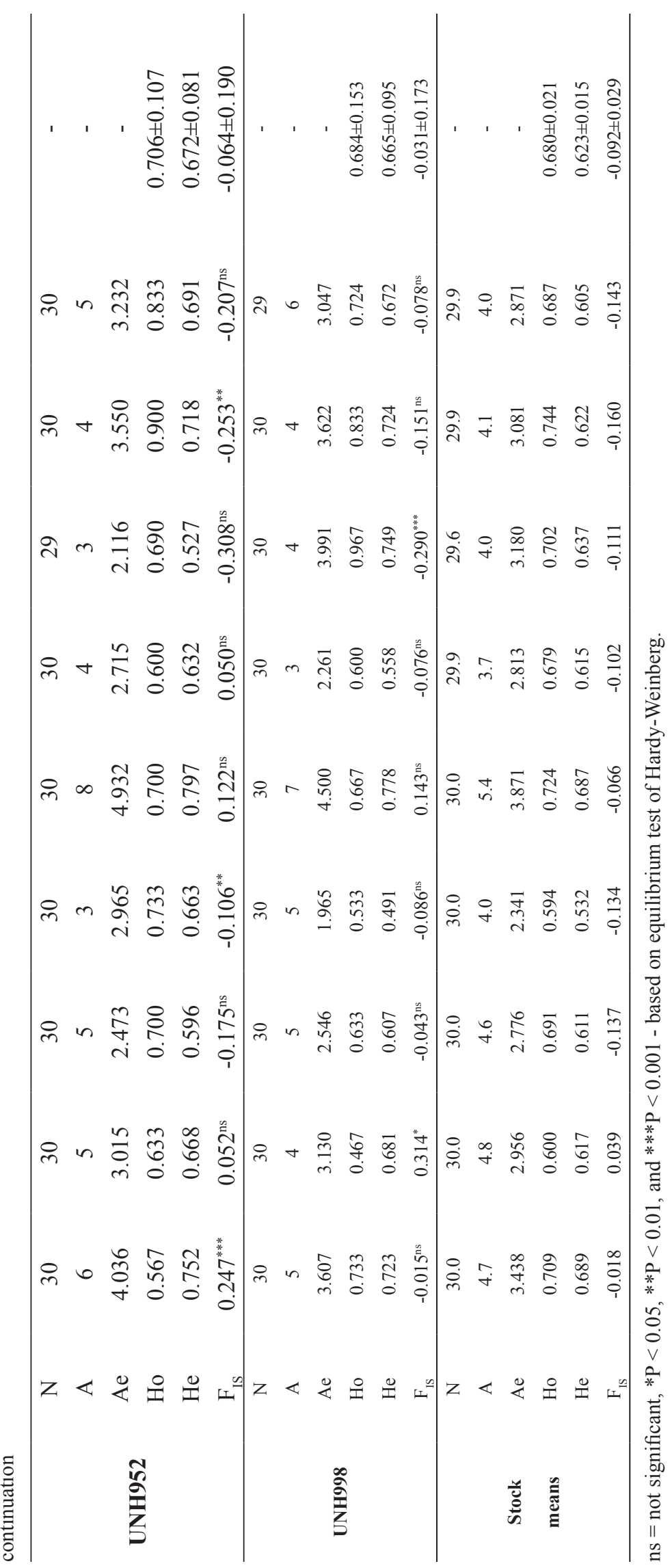


Regarding the Hardy-Weinberg equilibrium, it was observed that the number of loci per stock ranged from four to ten for populations S1 and S6, respectively. In addition, only the $\mathrm{UNH} 222$ locus is in equilibrium in all populations (Table 3). Given this information it is possible to make inferences about the significance (or not) of the $\mathrm{F}_{\text {IS }}$ values. In this regard, the UNH104, UNH208, UNH848, UNH868, and UNH879 loci showed exclusively negative values. As expected, from the analysis of null alleles (Table 2), stocks S1, S2, S3 and S5 showed significant values for $\mathrm{F}_{\mathrm{IS}}$, whose values were $0.573,0.806,0.380$ and 0.286 , respectively, for the loci UNH160 (Table 3). The average inbreeding coefficients per population ranged from -0.160 to 0.039 for stocks S8 and S2, respectively (Table 3).

In this study, the values of Ho were higher than $\mathrm{He}$, with the exception of the UNH160 marker, resulting in a negative mean inbreeding coefficient $\left(F_{\text {IS }}=-0.092\right)$. Thus, there is genetic variability within the studied brood stock, since the negative $\mathrm{F}_{\text {IS }}$ value indicates an excess of heterozygosity, which is interesting in a breeding program. In addition, all markers were polymorphic, showing satisfactory results for evaluating the genetic variability of this stock. In contrast to this study, RodriguezRodriguez et al. (2013) found a positive $\mathrm{F}_{\text {IS }}$ of 0.281 and attributed the lower heterozygosity observed in the breeding stock to the selection process used. Other studies in Brazil evaluating stock of the GIFT strain, which shared the same origin through a single import of 30 GIFT tilapia families from Asia to Brazil (Halfen et al., 2012), reported $\mathrm{F}_{\text {IS }}$ values of 0.16 and 0.35 (Petersen et al., 2012; Dias et al., 2016). Previously, Baggio et al. (2016) reported a $F_{\text {IS }}$ value for a stock of GIFT tilapia of -0.042 , a value close to that found in our study.

The excess of heterozygotes in a stock can occur when the fitness of these genotypes provides nonrandom mating in the previous generation, when the stock experiences a bottleneck due to the sample size (where few individuals contribute to the next generation); or when the number of individuals sampled in the current generation is small, and with that, genetic drift may occur. The last two conditions may justify the $\mathrm{F}_{\text {IS }}$ values found both in this study and in other studies in the literature.

Among the markers used in this study, some are already known to be regions of the genome associated with phenotypic traits of interest, known as Quantitative Trait Loci (QTL). According to Cnaani, Zilberman, Tinman, Hulata, \& Ron (2004), the markers UNH848, UNH868, and UNH898 are associated with tilapia weight characteristics, program focus trait, and together explain 37.9\% of the variation of this trait. The markers UNH848 and UNH868 also explain $24.4 \%$ of the variation in tilapia immunoglobulin M (IgM) data (Cnaani et al., 2004). These markers displayed greater observed heterozygosity than expected heterozygosity values, and showed the following values of inbreeding coefficient: UNH898 ( $\left.\mathrm{F}_{\text {IS }}=-0.019\right), \mathrm{UNH} 848\left(\mathrm{~F}_{\mathrm{IS}}=\right.$ $-0.223)$ and $\mathrm{UNH} 868\left(\mathrm{~F}_{\mathrm{IS}}=-0.158\right)$. Moreover, the UNH879 marker is associated with cold tolerance (Cnaani et al., 2003), an important trait to Santa Catarina, and also exhibited high heterozygosity and negative inbreeding coefficient ( $\mathrm{F}_{\text {IS }}$ de -0.182$)$. These results are important due to the need to verify how much genetic variability the base brood stock contains as the higher the genetic variability of the population, the greater the genetic gain through selection (Falconer, Mackay, \& Frankham, 1996). As such, it is possible to use these data and these markers in the breeding program. Information on the allele frequency of particular loci in animals with better performance for the trait of interest can be used in the selection process. For example, $\mathrm{H}$. P. Zhu et al. (2015) observed differential allelic segregation between cold-tolerant and cold-sensitive tilapia strains in the UNH916 and UNH999 markers and, according to the authors, this information can be used for marker-assisted selection programs in tilapia breeding.

In total, five private alleles were found, with one private allele in stock $\mathrm{S}$, and four private alleles in S5. In most cases, the private alleles had a low allele 
frequency, with the exception of allele 201 of the UNH952 loci (S5) which had an allele frequency of 0.200 (Table 4). The presence of private alleles is due to mutation, gene flow or allele display by selecting from other stocks. Possibly, in this study, these alleles are mutations over time of S5 stock formation, as this stock has no different origin to the other stocks. From these results, it is possible to monitor animals from the next generations of tilapia in Epagri's breeding program and to avoid possible genetic contamination at mating.

Table 5 shows that the greatest genetic variation in the brood stock is between individuals within a stock (89\%), not among stocks, showing what was reported in the previous paragraph, namely that the stock of GIFT tilapia in the Epagri program present a good variability between individuals (Moreira et al., 2007; Briñez et al., 2011; W. B. Zhu et al., 2017).

Table 4

Private alleles of the Nile tilapia stock from the Epagri breeding program

\begin{tabular}{cccc}
\hline Stock & Loci & Alleles & Allelic frequency \\
\hline S1 & 952 & 207 & 0.050 \\
S2 & - & - & - \\
S3 & - & - & - \\
S4 & - & - & - \\
S5 & $898 / 998 / 952 / 952$ & $282 / 119 / 201 / 234$ & $0.067 / 0.050 / 0.200 / 0.017$ \\
S6 & - & - & - \\
S7 & - & - & - \\
S8 & - & - & - \\
S9 & - & - & - \\
\hline
\end{tabular}

Table 5

Analysis of molecular variance (AMOVA) of microsatellite markers among nine brood stock of Nile tilapia from the Epagri breeding program

\begin{tabular}{ccccc}
\hline Source of variation & d.f. & Sum of Squares & Variance component & Percentage of variation (\%) \\
\hline Among stock & 8 & 232.943 & 0.427 & $11 \%$ \\
Within stock & 531 & 1855.200 & 3.494 & $89 \%$ \\
Total & 539 & 2088.143 & 3.921 & \\
\hline
\end{tabular}

$\mathrm{F}_{\mathrm{ST}}=0.109^{* * *} ; 9,999$ permutations.

The $\mathrm{F}_{\mathrm{ST}}$ found in this study for the second generation of GIFT tilapia in the Epagri program was 0.109 , indicating a moderate genetic differentiation between the brood stocks. The Epagri Research Group performed the genotyping of the first generation of GIFT tilapia and reported an $\mathrm{F}_{\mathrm{ST}}$ value for the brood stock of 0.239 (Silva, Pereira, \& Mariguele, 2016) with only seven of the eleven microsatellite markers. These data indicate that there was a decrease in the genetic differentiation between stocks from one generation to another. This decrease in the genetic differentiation is expected because artificial selection tends to select animals with the same alleles of interest over generations. As already mentioned, the negative $\mathrm{F}_{\mathrm{IS}}$ values indicate that there is good variability among the individuals in the breeding program, but genetic distances between the stocks appear to be decreasing. 
According to Euclidean distance, the dendrogram presented in Figure 1 was constructed, facilitating the verification of the distance between the different brood stocks used in the tilapia breeding of Epagri. Three groups were formed as follows: I - S6, S7 and S9; II - S2, S3 and S4; and III - S1, $\mathrm{S} 5$ and S8. According to Nei's genetic distances, the values ranged from 0.087 to 0.461 between stocks S2 / S3 and S4 / S7, respectively. The first three PCoA coordinates explain $90.98 \%$ of the variation among the studied stocks; the first, second and third correspond to 56.75, 24.84 and 9.40\% respectively. From the PCoA representation (Figure 2) the existence of two groups can be observed: I - S6, S7, S8 and S9 and II - S1, S2, S3, S4 and S5. The formation of these two genetic groups is consistent with the genealogy of stocks; stocks S1 to S5 have different origins from stocks S6 to S9. The formation of group III (S1, S5 and S8) in the dendrogram can be explained by the higher average observed heterozygosity values of these stocks (Table 3).

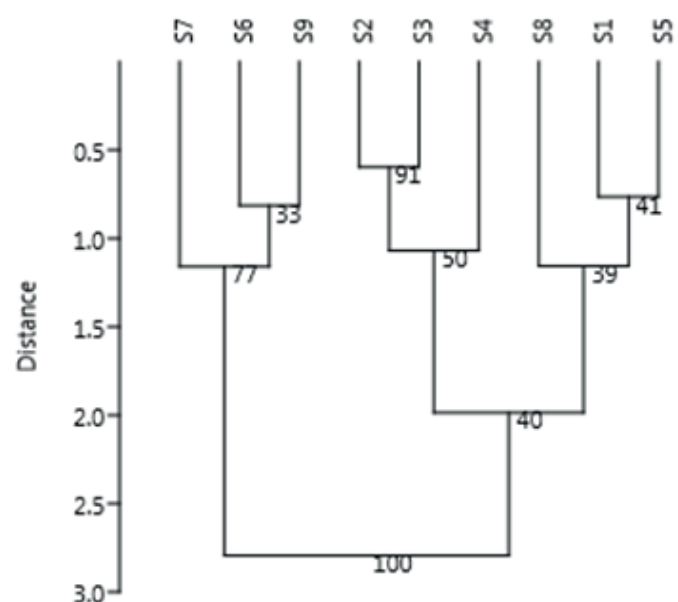

Figure 1. Dendrogram derived from Ward's method using Euclidean distance with 10,000 bootstrap samples between different brood stocks (S1 to S9) of Nile tilapia from the Epagri breeding program based on 11 SSR markers (UNH104, UNH108, UNH160, UNH208, UNH222, UNH848, UNH868, UNH879, UNH898, UNH952, UNH998).

\section{Principal Coordinates (PCoA)}

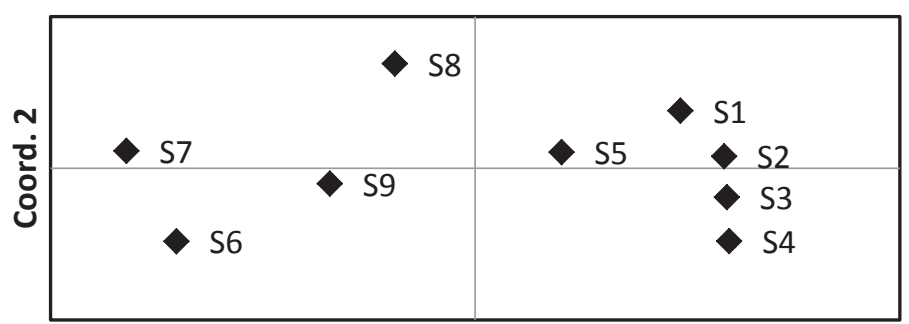

Coord. 1

Figure 2. Principal Coordinate Analysis of genetic distances of nine breed stock of Nile tilapia from the Epagri breeding program. 
Based on studies with different tilapia strains in Brazil and the rest of the world, it is possible to observe that, although the $\mathrm{F}_{\mathrm{ST}}$ value has decreased between generations, the $\mathrm{F}_{\mathrm{ST}}$ value found in this study is of considerable value to determine genetic differentiation between brood stocks.

Rodriguez-Rodriguez et al. (2013), after genetic characterization of different generations of tilapia (GIFT strain) derived from a family-based breeding program, also observed moderate values for genetic differentiation $\left(\mathrm{F}_{\mathrm{ST}}\right)$ among the generations of GIFT tilapia (0.014 to 0.081$)$. Other studies comparing different strains cultivated in Brazil found moderate values for genetic differentiation, with $\mathrm{F}_{\mathrm{ST}}$ values of 0.130 and 0.131 , respectively, in the studies of Petersen et al. (2012) and Moreira et al. (2007).
The approximate values of $\mathrm{F}_{\mathrm{ST}}$ in different studies comparing different stocks of tilapia rearing in Brazil is understandable, since much of the GIFT tilapia produced in the country so far have derived from a single import, as was the case with red tilapia and Chitralada tilapia.

The implemented Bayesian analysis was applied in order to generate genetically homogeneous groups among 270 pre-defined individuals in nine stocks (Figure 3). From this analysis, the formation of 16 groups with an $\mathrm{F}_{\mathrm{ST}}$ value of 0.2107 was established. This result reinforces the existence of variability existing in the Epagri breeding program, from which it is possible to form heterotic groups to enable the direction of potential crosses to obtain genetic benefits.

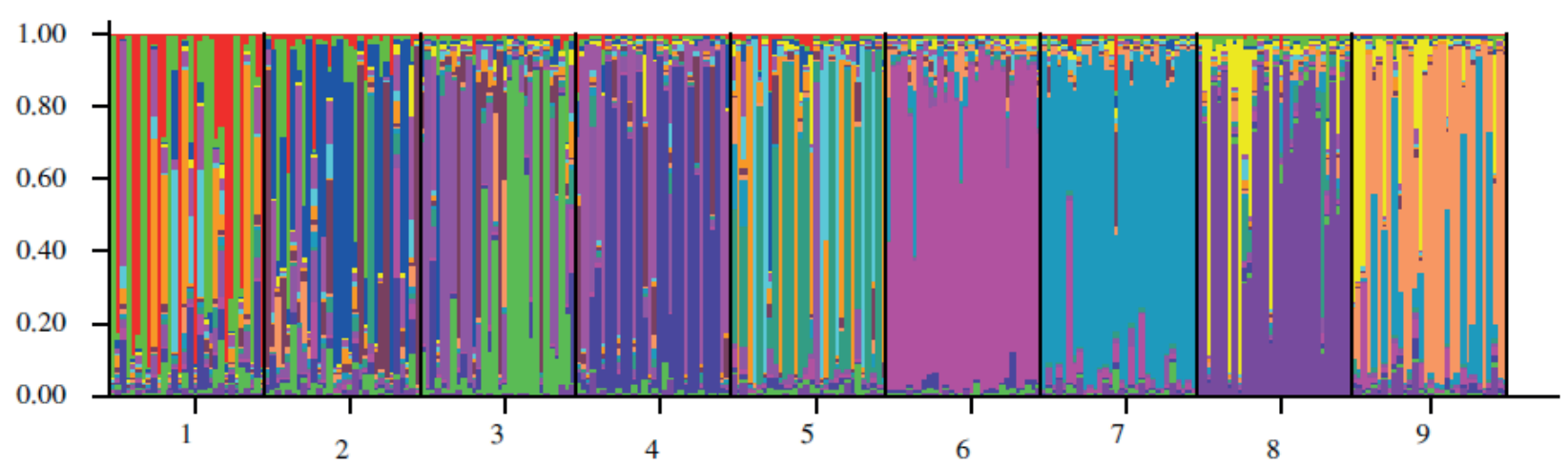

Figure 3. Allocation of 270 tilapia GIFT individuals of nine breed stock $(K=16)$ of Nile tilapia from the Epagri breeding program.

\section{Conclusions}

The study enabled genotypic characterization of the tilapia brood stock used in the Epagri breeding program, determining the genetic distance between the stocks, which will enable more accurate selection of individuals for mating for the next generation. It was possible to verify that there is high heterozygosity within the stocks, and moderate genetic differentiation between the stocks. Furthermore, all markers evaluated were polymorphic for this brood stock and will be used to characterize the next generations.

\section{Acknowledgements}

We thank the Conselho Nacional de Desenvolvimento Cientifico e Tecnológico (CNPq) (CNPq 444577/2014-9)" and the Fundação de Amparo à Pesquisa e Inovação do Estado de Santa Catarina (FAPESC - Project number 2017TR1709) for financial support. We would also like to thank Silvio Demarch Filho, Leandro Bortoli, Silvano Garcia, João Burg and Karla Geovana Weiss de Souza for technical support. 


\section{References}

Aljanabi, S. M., \& Martinez, I. (1997). Universal and rapid salt-extraction of high quality genomic DNA for PCR-based techniques. Nucleic Acids Research, 25(22), 4692-4693. doi: 10.1093/nar/25.22.4692

Associação Brasileira de Piscicultura (2018). Anuário da Piscicultura 2018. Recuperado de http://www. peixebr.com.br/anuario-peixebr-2018/

Baggio, R. A., Orélis-Ribeiro, R., \& Boeger, W. A. (2016). Identifying Nile tilapia strains and their hybrids farmed in Brazil using microsatellite markers. Pesquisa Agropecuária Brasileira, 51(10), 17441750. doi: 10.1590/s0100-204x2016001000006

Barroso, R., Tenório, R., Pedroza, M. X., Fº, Webber, D., Belchior, L., Tahim, E., \& Muehlmann, L. (2016). Gerenciamento genético da tilápia nos cultivos comerciais. Palmas: EMBRAPA Pesca e Aquicultura-Documentos. Recuperado de http:// www.infoteca.cnptia.embrapa.br/infoteca/handle/ doc/1036709

Bentsen, H. B., Gjerde, B., Eknath, A. E., Vera, M. S. P., Velasco, R. R., Dantins, J. C.,... Ponzoni, R. W. (2017). Genetic improvement of farmed tilapias: Response to five generations of selection for increased body weight at harvest in Oreochromis niloticus and the further impact of the project. Aquaculture, 468(1), 206-217. doi: 10.1016/j. aquaculture.2016.10.018

Briñez B. R., Caraballo, X. O., \& Salazar, M. V. (2011). Genetic diversity of six populations of red hybrid tilapia, using microsatellites genetic markers. Revista MVZ Córdoba, 16(2), 2491-2498. Retrieved from http://www.scielo.org.co/pdf/mvz/v16n2/v16n2a06. pdf

Brookfield, J. F. Y. (1996). A simple new method for estimating null allele frequency from heterozygote deficiency. Molecular Ecology, 5(3), 453-455. doi: 10.1046/j.1365-294X.1996.00098.x

Cnaani, A., Hallerman, E. M., Ron, M., Weller, J. I., Indelman, M., Kashi, Y., \& Hulata, G. (2003). Detection of a chromosomal region with two quantitative trait loci, affecting cold tolerance and fish size, in an F 2 tilapia hybrid. Aquaculture, 223(1), 117-128. doi: 10.1016/S0044-8486(03)00163-7

Cnaani, A., Zilberman, N., Tinman, S., Hulata, G., \& Ron, M. (2004). Genome-scan analysis for quantitative trait loci in an F2 tilapia hybrid. Molecular Genetics and Genomics, 272(2), 162-172. doi: 10.1007/ s00438-004-1045-1
Dias, M. A. D., Freitas, R. T. F., Arranz, S. E., Villanova, G. V., \& Hilsdorf, A. W. S. (2016). Evaluation of the genetic diversity of microsatellite markers among four strains of Oreochromis niloticus. Animal genetics, 47(4), p. 345-353. doi: 10.1111/age.12423

Falconer, D. S., Mackay, T. F. C., \& Frankham, R. (1996). Introduction to quantitative genetics (4nd ed.). Longman, England: Trends in Genetics.

Falush, D., Stephens, M., \& Pritchard, J. K. (2003) Inference of population structure using multilocus genotype data: Linked loci and correlated allele frequencies. Genetics, 164(4), 1567-1587. Retrieved from https://www.genetics.org/content/ genetics/164/4/1567.full.pdf

Gjedrem, T. (2010). The first family $\square$ based breeding program in aquaculture. Reviews in Aquaculture, 2(1), 2-15. doi: 10.1111/j.1753-5131.2010.01011.x

Halfen, G. E., Nicoletti, M. E., Appel, H. B., \& Tcacenco, F. A. (2012). Caracterização molecular de plantéis de tilápia do Nilo (Oreochromis niloticus L.) em Santa Catarina, Brasil. Journal of Biotechnology and Biodiversity, 3(2), 21-29. doi: 10.20873/jbb.uft. cemaf.v3n2.halfen

Hammer, Ø., Harper, D. A., \& Ryan, P. D. (2001). PAST: paleontological statistics software package for education and data analysis. Palaeontologia Electronica, 4(1), 9. Retrieved from https:// www.academia. edu/download/39675641/PAST Paleontological_Statistics_Software2015110427951-163povm.pdf.

Hassanien, H. A., \& Gilbey, J. (2005). Genetic diversity and differentiation of Nile tilapia (Oreochromis niloticus) revealed by DNA microsatellites. Aquaculture Research, 36(14), 1450-1457. doi: 10.1111/j.1365-2109.2005.01368.x

Joshi, D., Ram, R. N., \& Lohani, P. (2017). Microsatellite markers and their application in fisheries. International Journal of Advances in Agricultural Science and Technology, 4(10), 67-104. Retrieved from https://pdfs.semanticscholar.org/dade/2da0e8a 8900b7b1d0d8c866337cdceb8c934.pdf

Kubitza, F. (2015). Aquicultura no Brasil: principais espécies, áreas de cultivo, rações, fatores limiitantes e desafios. Panorama da Aquicultura, 25(150), 1023. Retrieved from http://www.ferrazmaquinas. com. br/uploads/conteudo/conteudo/2016/09/cyKAX/ aquicultura-no-brasil.pdf

Moraes, B. G., Saldanha, G. B., Rezende, J. V. F., \& Sousa, B. M. (2017). Melhoramento genético animal aplicado à aquicultura: atualidade e perspectivas 
futuras nos programas de melhoramento de tilápia (Oreochromis Niloticus) no Brasil. Sinapse Múltipla, 6(2), 336-340. Retrieved from http://periodicos. pucminas.br/index.php/sinapsemultipla/article/ view/16525/12711.

Moreira, A. A., Hilsdorf, A. W., Silva, J. V., \& Souza, V. R. (2007). Variabilidade genética de duas variedades de tilápia nilótica por meio de marcadores microssatélites. Pesquisa Agropecuária Brasileira, 42(4), 521-526. doi: 10.1590/S0100204X2007000400010

Peakall, R. O. D., \& Smouse, P. E. (2006). GENALEX 6: genetic analysis in Excel. Population genetic software for teaching and research. Molecular Ecology Notes, 6(1), 288-295. doi: 10.1111/j.14718286.2005.01155.x

Petersen, R. L., Garcia, J. E., Mello, G., Liedke, A. M. R., Sincero, T. C. M., \& Grisard, E. C. (2012). Análise da diversidade genética de tilápias cultivadas no estado de Santa Catarina (Brasil) utilizando marcadores microssatélites. Boletim Instituto de Pesca, 38(4), 313-321. Retrieved from https://www.pesca.sp.gov. br/ boletim/index.php/bip/article/view/966

Pritchard, J. K., Stephens, M., \& Donnelly, P. (2000) Inference of population structure using multilocus genotype data. Genetics, 155(2), 945-959. Retrieved from https://www.genetics.org/content/genetics/ 155/2/945.full.pdf.

RodriguezRodriguez, M. P., LoperaBarrero, N. M., Vargas, L., Albuquerque, D. M., Goes, E. S. R., Prado, O. P. P., \& Ribeiro, R. P. (2013). Caracterização genética de gerações de tilápia Gift por meio de marcadores microssatélites. Pesquisa Agropecuária Brasileira, 48(10), 1385-1393. doi: 10.1590/S0100204X2013001000010
Romana-Eguia, M. R. R., Ikeda, M., Basiao, Z. U., \& Taniguchi, N. (2004). Genetic diversity in farmed Asian Nile and red hybrid tilapia populations evaluated from microsatellite and mitochondrial DNA analysis. Aquaculture, 236(1-4), 131-150. doi: 10.1016/j.aquaculture.2004.01.026

Schuelke, M. (2000). An economic method for the fluorescent labeling of PCR fragments. Nature Biotechnology, 18(2), 233-234. doi: 10.1038/72708

Silva, B. C., Pereira, A., \& Mariguele, K. H. (2016). Variabilidade genética com SSR de populações de tilápia-do-nilo da linhagem Gift-Epagri. Anais da Semana Acadêmica do Curso de Engenharia de Aquicultura da UFSC, Florianópolis, SC, Brasil, 14.

Van Oosterhout, C., Hutchinson, W. F., Wills, D. P. M., \& Shipley, P. (2004). Micro-Checker: software for indentifying and correcting genotyping errors in microsatellite data. Molecular Ecology Notes, 4(3), 535-538. doi: 10.1111/j.1471-8286.2004.00684.X

Webster, C. D., \& Lim C. (Ed.). (2006). Tilapia: biology, culture, and nutrition. New York, USA: The Haworth Press.

Zhu, H. P., Liu, Z. G., Lu, M. X., Gao, F. Y., Ke, X. L., \& Huang, Z. H. (2015). Screening and identification of microsatellite markers associated with cold tolerance in Nile tilapia Oreochromis niloticus. Genetics and Molecular Research, 14(3), 10308-10314. doi: $10.4238 / 2015$

Zhu, W. B., Yang, H., Yuan, X. H., Dong, Z. J., Fu, J. J., Wang, L. M.,... Chen, X. T. (2017). High genetic diversity and differentiation in three red tilapia populations revealed by microsatellite DNA marker analysis. Aquaculture International, 25(6), 19972006. doi: 10.1007/s10499-017-0150-1 
